\title{
Palmas, the last capital city planned in twentieth-century Brazil
}

\author{
Palmas, a última capital planejada no Brasil do século XX
}

Renato Leão Rego[a] [1]

[a] Universidade Estadual de Maringá (UEM), Maringá, PR, Brasil

How to cite: Rego, R. L. (2020). Palmas, the last capital city planned in twentieth-century Brazil. urbe. Revista Brasileira de Gestão Urbana, 12, e20190168. https://doi.org/10.1590/2175-3369.012.e20190168

\section{Abstract}

Palmas is the capital of a new state created in order to foster regional development in central Brazil. This new town was planned from scratch in 1989, during the country's re-democratization process, between the postmodernist criticism of functionalist planning and rising environmental concerns. However, its layout depicts a mixed relationship with Brasília-style urbanism. Covering a timeframe of thirty years (1989-2019), this paper presents an outline of the history and planning of Palmas, followed by an assessment of its plan and an exploration of its contemporary major urban challenges. It contrasts the planners' original ideas with the built city, and unveils late modernist features that have been rejected and transformed. Essentially, Palmas is a modernist new capital city planned in postmodernist times.

Keywords: New town. Regional planning. Urban design. Planning diffusion. Developing country.

\section{Resumo}

Palmas é a capital de um novo estado criado no interior do Brasil para fomentar o desenvolvimento regional. Esta nova cidade foi planejada em 1989, durante o processo de redemocratização do país, em meio à crítica ao urbanismo modernista e às crescentes preocupações ambientais. Contudo, seu traçado revela uma relação mista com o urbanismo de Brasília. Cobrindo um intervalo de trinta anos (1989-2019), este artigo apresenta uma narrativa da história e do planejamento de Palmas, seguida de uma avaliação do seu traçado e da exploração dos seus maiores desafios contemporâneos. O artigo contrasta as ideias originais dos urbanistas com a cidade construída, e revela aspectos modernistas tardios que têm sido rejeitados e transformados. Na essência, Palmas é uma nova capital modernista planejada em tempos pós-modernistas.

Palavras-chave: Cidades novas. Planejamento regional. Traçado urbano. Circulação de ideias. País em desenvolvimento. 


\section{Introduction}

Palmas (Figure 1), the capital city of the recently-created state of Tocantins in central Brazil, was designed from scratch in 1989 amid Brazil's re-democratization process, post-modernist criticism of modernist planning and the "functional city", and rising environmental concerns. The end of the military regime (1964-1985) and the promulgation of a new federal constitution in 1988 led to the creation of the new state, and the post-dictatorship period and accompanying economic recession turned the foundation of its capital city into an opportunity for regional development, economic growth and social progress, as the creation of Brasília had done before it.

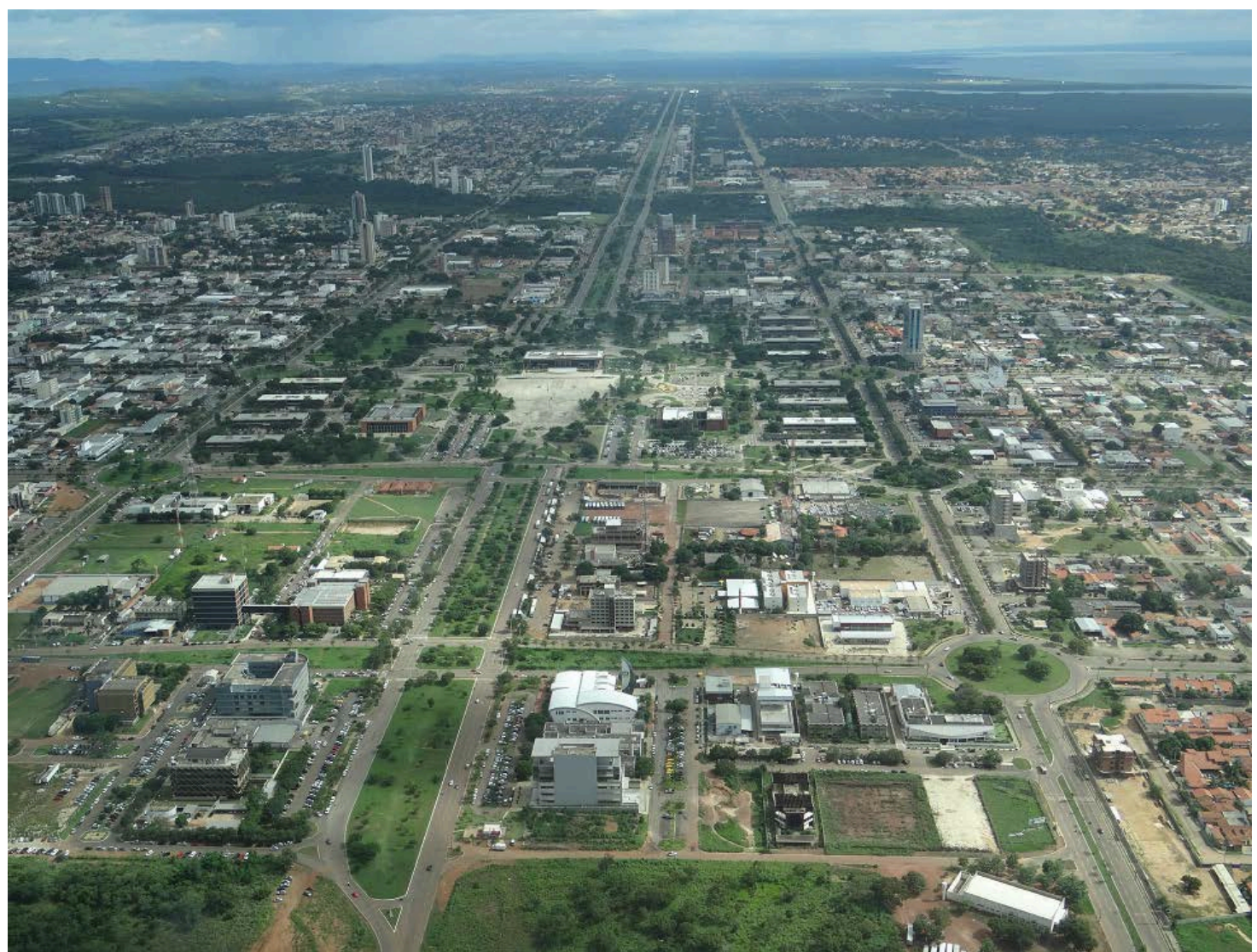

Figure 1 - Aerial view of Palmas, 2015. Governmental Palace in the centre. Source: Acervo LabQUAPÁ FAUUSP.

The concept of the "functional city", the most significant theoretical approach of CIAMs - the Congrès Internationaux d'Architecture Moderne - began to dominate its discourse in early 1930s (Mumford, 2000, p. 59). Le Corbusier had called for a "doctrine of urbanism" saying that CIAM should attempt to link "architecture and town planning with social evolution". CIAMs not only defended four urban functions of dwelling, work, transportation, and recreation but also advocated combining the abstract, defamiliarizing strategies of modern art with an aggressive celebration of new construction technologies (Mumford, 2009, p. 4 and 7).

This modernist approach and the urban experiments of Brasília and Chandigarh, in India, spawned a series of copies, and governments across Asia, Africa and South America have been proposing the building of new capitals ever since. In pursuit of varying agendas, new capital cities were built in Myanmar, Malawi, Ivory Coast, Malaysia, Pakistan, Kazakhstan and Palau. In post-independence African countries, such as Nigeria, Tanzania, Mauritania and Botswana, new capital cities were built to make a break from the colonial past, promote the building of a nation, and foster the development of their territories. Like Brasília, Abuja (1979) and Dodoma (1976) replaced Nigeria's and Tanzania's old coastal capitals in order to stimulate the economy of neglected central regions (Cain, 2014, p. 562; 
Vale, 2008, p. 160 and 175; Abubakar, 2014, p. 82; Hayuma, 1980; Siebolds \& Steinberg, 1980). Although based on the garden-city model, Abuja and Dodoma, in addition to Gaborone and Lilongwe, were planned along modernist lines (Abubakar \& Doan, 2010). The architectural forms promoted by modernist planning have, therefore, still shaped urban environments in the building of new capital cities in developing countries (UN-Habitat, 2009, p. 58), and Palmas is no exception.

The new capital cities in late twentieth-century developing countries were mainly founded for the transfer of power from existing capitals. The infrastructures and facilities that existed in the previous capitals were replicated in other parts of their countries, becoming positive stimuli for growth within their localities and nations. The moving of capitals to new permanent locations has been a catalysis for economic and infrastructural development (Alayande, 2006). However, the modernist planning efforts in Africa have increasingly been viewed with skepticism: although the grand plans for these new capitals emphasized orderly urban development through land-use planning and strict zoning, their outcomes have promoted regional development but also failed to avoid spatial exclusion and social inequality. Although Palmas is the first capital city of Tocantins, the effects of its creation were no different.

Created out of political and economic imperatives and instilled with expectations of transformation, the new state of Tocantins and its capital were conceived of with a similar reasoning to the African new capital cities. Like in those African countries, the creation of the new capital in central Tocantins state was to activate a new focal point for economic development and, indeed, Palmas has had a considerable impact on the underdeveloped region where it was built. Three decades after its foundation, Palmas has proved to be a stimulus for regional development, displaying notable territorial, economic and social achievements (Kran \& Ferreira, 2006). Palmas, the last capital city created in twentieth-century Brazil, effectively became a new horizon, both symbolically and literally.

Originally planned for one-and-a-half-million citizens, Palmas has today an estimated population of roughly three-hundred-thousand inhabitants and is growing at an impressive rate. From 1998 to 2003, prospects of a better life in the new capital attracted migrants and thus Palmas experienced an average population growth of 28.7 percent a year, whereas the overall rate in Brazil for the same period was only three percent (Trindade, 2009, p. 79). Over the last ten years, Palmas' population has grown at an average of more than 5 percent a year, boasting the highest population growth in Brazil during the last decade (Albieri, 2018, p. 206-207). Palmas has initiated inland development, especially agribusinesses, and its economy specializes in professional and technical services, having mainly drawn in workers from the north and northeast of Brazil. The city boasts the tenth highest per-capita GDP and the highest average wage in Tocantins state. In 2010, its Human Development Index (HDI) was 0.788, a higher index than the country's national rate, although this only placed it in $76^{\text {th }}$ position among the cities of Brazil (IBGE, 2017a). It has achieved a considerable quality of life in general (Kran \& Ferreira, 2006); the whole city is served with piped drinking water and garbage collection and disposal, and $73 \%$ of the urban area has had sanitation services (IBGE, 2017b).

Palmas depicts a singular layout, built along those of seminal model cities, and is consonant with local geography. The city is known as an "ecological capital" because of its substantial green open spaces. Palmas was allegedly designed to respond to the world of the average citizen (Trindade, 2009, p. 73-74); nevertheless, as this paper will show, modernism's idealized urban life was not completely abandoned in the new capital-city layout. Palmas' image is very much that of a modernist city, with the related modernist planning issues (UN-Habitat, 2009, p. 10).

This paper accounts for the late modernism of Palmas as part of a recurrent quest for progress and national identity in the country's history, and discusses its imposing and contested urban form.

Considering planning history and urban morphology studies, it presents the findings of an interpretative-historical research. I start with an historical overview of Palmas' three decades of existence (1989-2019), focusing on design concepts, planning context and the resulting city layout. Then I consider recent urban evolution, identifying the discrepancies between the original plan and its implementation. Next, I highlight certain residents' rejections of the built urban form and the ensuing transformations to the initial layout. Concluding remarks consider challenges likely to be faced in the city in the near future. 


\section{New towns as signs of progress and promoters of regional development}

In Brazil, like in other developing countries, the effort to transform the physical environment has been taken as a manifestation of development and has also served the nation-building discourse. Moreover, urbanization has been deemed a path to modernization, which led Brazilian democratic governments and dictatorships to create, and foster the creation of, new towns. Goiânia (1933-1936), Brasília (1957-1961) and Palmas (1989), the three capital cities planned in Brazil during the twentieth century, epitomized the governmental endeavour to occupy the territory, develop the country and build the nation (Almandoz, 2015, p. 93; Moraes, 2008; Gorelik, 2005; Trindade, 2009, p. 65; Rego, 2018).

The construction of Goiânia, the new capital of Goiás state, characterized the policy of the authoritarian, centralizing, nationalistic federal government that exalted past territorial occupation to foster the development of the hinterlands. President Getúlio Vargas' administration (1930-1945) aimed at creating a new society as part of an urban, industrialized, modern country, and the period known as Estado Novo (New State, 1937-1945) was indeed an important phase for Brazilian industrial capitalism, with a shift from the agro-export economy to an urban-industrial one (Rezende, 2012, p. 12; Almandoz, 2008, p. 66-67; Gomes, 2013, p. 43). Modernist architecture became one of its most emblematic symbols. The design of Goiânia, whose 1936 final version ended up mirroring the layout of Radburn (Rego, 2014, p. 288), was presented as "[...] the result of capitalist expansion in a new era for the national economy" (Lima, 1937, p. 32).

Brasília was the project of a democratic government, again committed to the modernization of the country and the development of its inner territory. It represented the apex of governmental development policies and cultural optimism (Del Rio, 2009, p. 9). With the slogan of "fifty years of progress in five years of government", President Juscelino Kubitschek (1956-1961) proposed an economic model that favoured the association of Brazilian private companies with multinational and state corporations, which was successful in the short term as national rates for economic growth peaked at 10\% (Almandoz, 2015, p. 92; Del Priore \& Venancio, 2010, p. 268). President Kubtischek's drive for industrialization was pivotal in the population explosion of major Brazilian cities in the 1950s, as Vargas' had been in the 1940s (Del Rio, 2009, p. 8). Inaugurated in 1961, just at the beginning of the "Decade of Development", the new federal capital was to create a new social order through an innovative urban form that radically re-conceptualized city life (Gorelik, 2005, p. 49; Holston, 1989).

The military regime (1964-1985) did not build a capital city, but planned a series of new towns along the recently opened highway through the Amazonian Forest in the early 1970s (Rego, 2017a). Among other mammoth governmental enterprises, the Transamazonian Highway and its colonization and settlement scheme were part of a policy to develop the country, aiming at social transformation and national integration. Transamazonian new towns, built upon modernist layouts, were expected to give birth to "a new civilization" (Camargo, 1973, p. 7). The highway construction was an attempt to revive the euphoria of the era of the Brasília project (Del Priore \& Venancio, 2010, p. 284) and played an important symbolic role as an image of the "Great Brazil" in this nationalist period of exceptional development. The early 1970s were called the "age of economic miracle", when the Gross Domestic Product leapt from $9.8 \%$ in 1968 to $14 \%$ in 1973, although the international oil crisis and the high inflation and massive unemployment of 1974, and its subsequent economic recession, marked the 1980s as the "lost decade" (Almandoz, 2008, p. 71). 


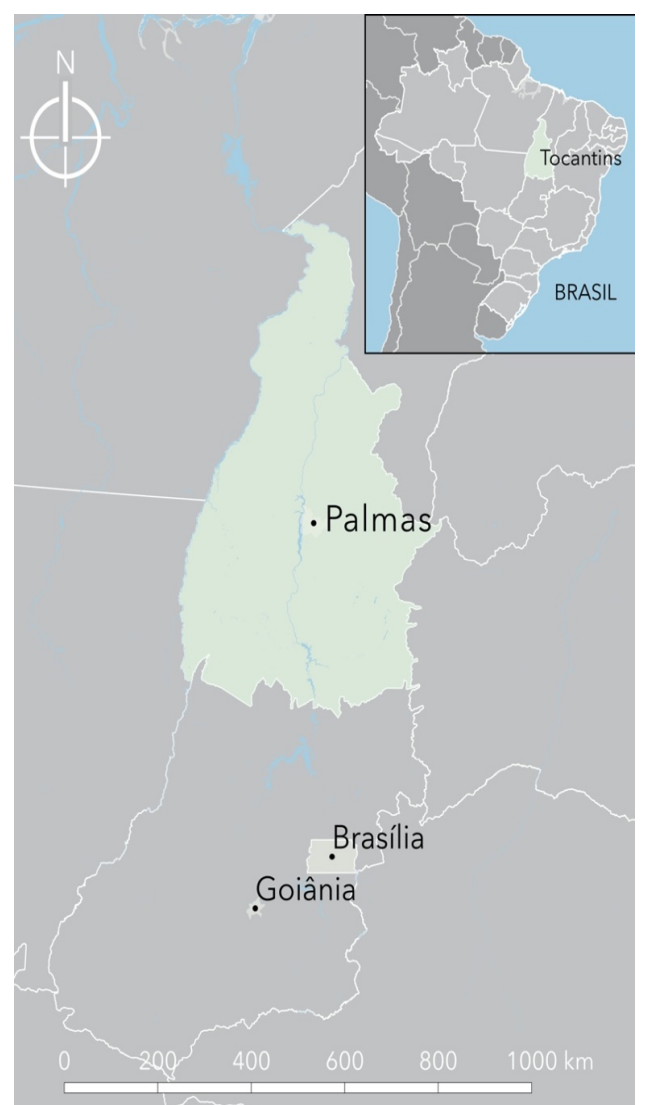

Figure 2 - Map of Tocantins state. Source: IBGE (2017a), modified by the author.

In the post-dictatorship period of economic recession, amid local setbacks, intensification of social movements, post-modernist criticism and ecological thought, the creation of a new state and its capital city was again seen as a potential opportunity to give rise to progress and regional development (GrupoQuatro, 1991, p. 95; Trindade, 2009, p. 65). An impoverished territory was detached from the vast state of Goiás and the new state of Tocantins was born. It was described as being rural, with unexploited mineral and hydroelectric potential, only partially fulfilling its agricultural potential and relying on cattle raising, and enduring a socio-economic chaos (Bittar, 1988, p. 40; Reis, 2015a, p. 18. Figure 2). Like the other two capital cities planned in twentieth-century Brazil - and the post-colonial African cities-, Palmas and the regional infrastructure network necessary to serve a capital city were to develop and modernize the hinterland by being a centre for human resources and a point of integration for the north, north-east and central-west regions of the country (Velasques, 2010, p. 44). A state capital of a democratic age, Palmas reveals a mixed relationship with Brasília's urbanism. The new federal capital of Brazil was also created in a democratic period but was consolidated during the military regime and its layout can thus be mistaken as the product of the authoritarian aspect of those days (Segawa, 1997, p. 197). Although constructed under very different political circumstances, the speedy creation of Palmas ${ }^{1}$ was once again intended to project a novel urban image of progress, development and modernization.

\section{A late-modernist layout}

The capital of Tocantins was planted in an underdeveloped region, eight-hundred kilometres north of Brasília. Palmas lies on a long, fifteen-kilometre wide, flat terrain in the geographic centre of the state and its north-south linear layout is a design response to the site (Figure 3). The city is situated at 260 metres

\footnotetext{
${ }^{1}$ Palmas' planning started in late 1988 and the new capital city was inaugurated in 1989. In contrast to Palmas and Brasília, Abuja, from its conception in 1976 to the materialization of its first phase in 1991, had taken 15 years.
} 
above sea level between the right bank of the Tocantins River on the west side and the Lajeado hill range on the east side. The natural barrier formed by the hill, turned into an ecological reserve, rises up to 600 metres above sea level. The site chosen for the new city was crossed by streams and creeks and covered by vegetation that is typical of the cerrado - the Brazilian savanna. The setting was chosen due to the site morphology and its singular landscape, natural resources, ecology and accessibility, and the design approach valued the preservation of, and integration into the natural environment (Velasques, 2010, p. 48; Trindade, 2009, p. 68; Albieri, 2018, p. 200). The environmental concern related to the location of a new city was in tune with the contemporary (post-modernist) ecological thought, as stated by the planners (GrupoQuatro, 1991, p. 95).

Apart from its natural setting, the gigantic grid, wide avenues, functional zoning and the adaptation of the neighbourhood unit concept are memorable features of Palmas. References to the design of the new capital city can be observed by tracking its planners' professional trajectories. Architects Luiz Fernando Cruvinel Teixeira and Walfredo Antunes de Oliveira Filho both lived in Goiânia, studied at the University of Brasília and attended post-graduate courses in London: Teixeira did two courses at the Architectural Association (Tropical Studies in 1969 and Town Planning and Design in 1974) and Oliveira Filho specialized in landscape architecture before getting a master's degree in Regional Planning from the London School of Economics in 1980 (Velasques, 2010, p. 70-75). Palmas' planners had visited Milton Keynes, the English new town planned in late 1960, which was immediately considered one of the most "[...] celebrated places in the broad landscape of twentieth-century urban planning" (Wakeman, 2016, p. 212). Milton Keynes, Brasília and Goiânia were therefore their planning models (Trindade, 2009, p. 68; Segawa, 1991).

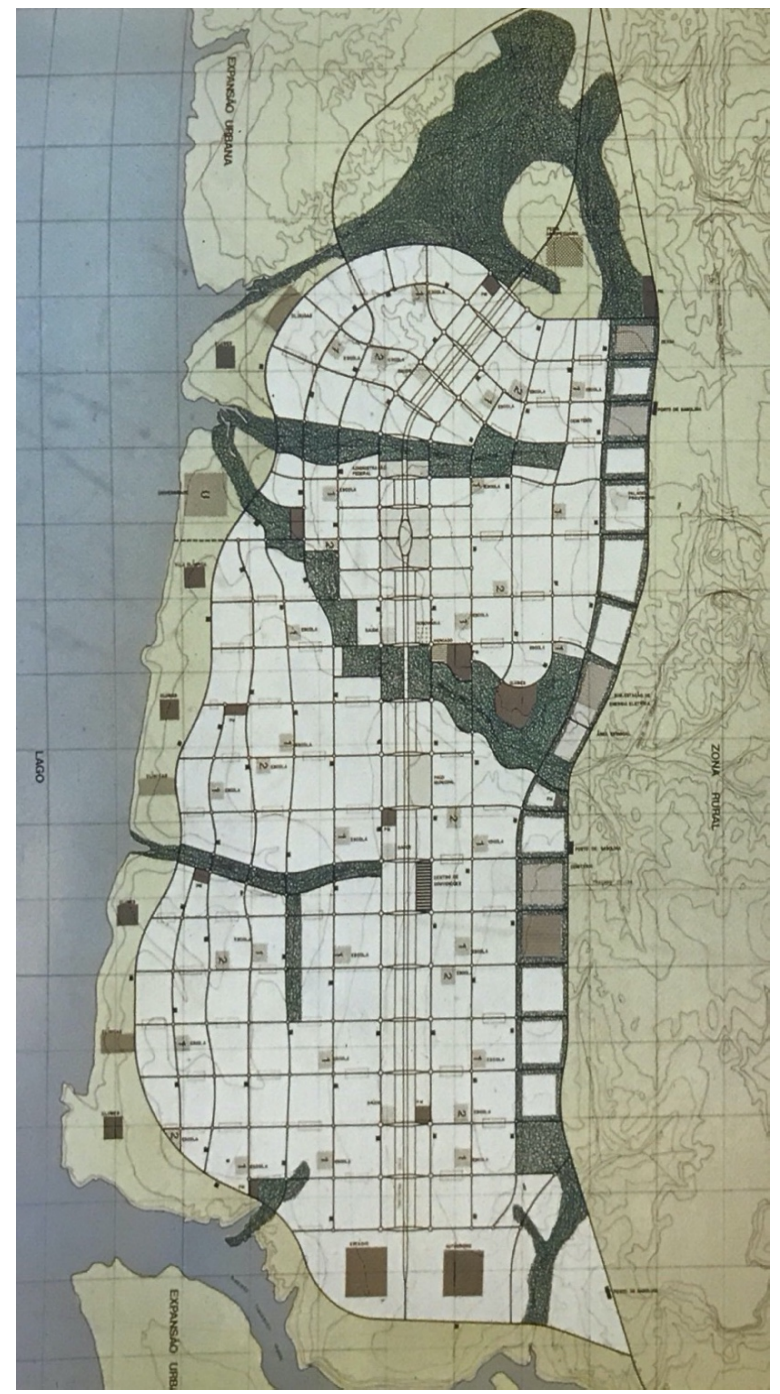

Figure 3 - Original plan of Palmas, 1989. Source: Segawa (1991). 
Teixeira and Oliveira Filho set the avenue grid of Palmas at 700×700 metres (49 hectares). Brasília's superblocks were far smaller (28 hectares) and less dense. Palmas' planners were aware that a bigger grid - e.g. 100 hectares in Milton Keynes or 96 hectares in Chandigarh - would be less expensive, but the plan's smaller distances were allegedly designed to favour pedestrian and community life. The proposed grid was oriented to the cardinal points in respect of dominant winds.

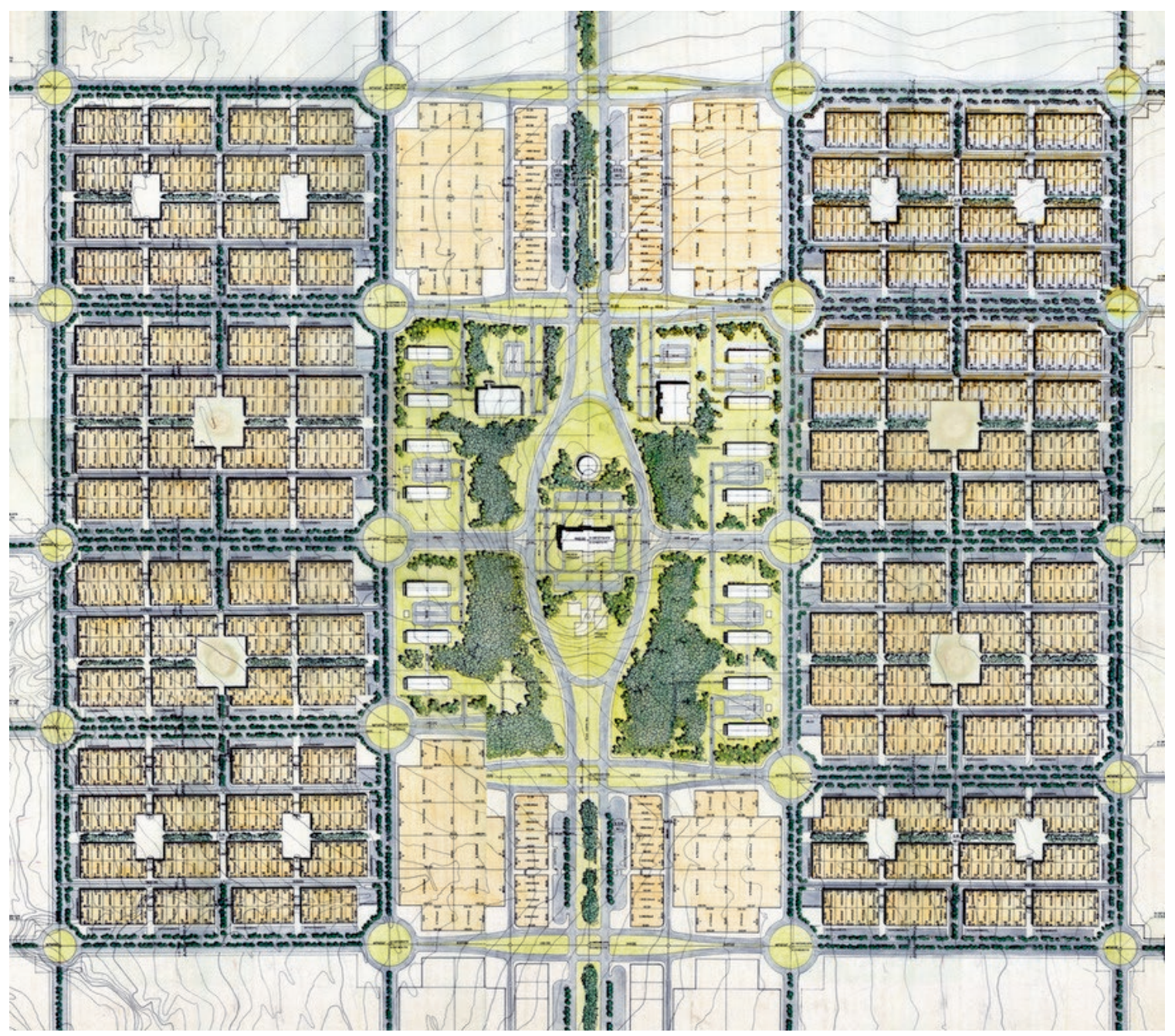

Figure 4 - Original layout of Palmas civic centre. Source: Velasques (2010).

Like the plan for Milton Keynes, Palmas also presents a loose network that is adjusted to site conditions, which is defined by wide avenues that benefit traffic and favour the use of private transportation. Brazilian modernist architecture and urbanism have long been enchanted by the motorcar (Lara, 2018); moreover, the Charter of Athens, a product of CIAM, segregates the main town functions, all of which are designed to be connected by motorcars (Mumford, 2000). In Palmas' plan, it was no different. North-south Brasília-style highways, the longest and main urban roads, and their perpendicular east-west shorter avenues are articulated by roundabouts. East-west avenues distribute the hierarchical traffic to the residential areas, located in "macroblocks". The layout of Milton Keynes was itself non-hierarchical and flexible, without a city centre and presenting low density, notable by its openness and greenery - a return to the garden-city concept (Wakeman, 2016, p. 214-215; Osborn \& Whittick, 1977, p. 237). In Palmas, though, the design portrays a relative centrality (the administrative centre, seat for the state authorities and reason for the city's existence) in an otherwise non-hierarchical linear form (Teixeira et al., 1991, p. 104, Figure 4). Thus, a central longitudinal north-south axis organizes 
the city form and leads to the civic centre, called Praça dos Girassóis: an area of 63 hectares that holds administrative, legislative and justice buildings, with the governor's palace set on a slightly elevated area.

Palmas' layout is still marked by a hierarchy of specific functions as outlined in the Charter of Athens (Trindade, 2009, p. 69). Commercial buildings were classified in four categories (regional, urban, vicinal and local), and were distributed in specific areas over the city. Thus, a central commercial area is located around the central park: a pedestrian zone, according to the original design, containing stores, offices, businesses, company headquarters and banks. Industrial and regional-scale commerce and services areas are located on the city periphery. Along the central axis are located the urban-scale commerce and services areas, and beyond them, the residential macroblocks, which hold local commerce for daily life and, thus, according to the original concept, would remove the need for local residents to leave the residential blocks and cross the highways for their daily shopping necessities. On the edge of every macroblock, vicinal commerce was to be established facing the east-west avenues (GrupoQuatro, 1991, p. 99).

The original land-use allocation was roughly $37 \%$ for residential, $8 \%$ for commercial and services, $18 \%$ for institutional, governmental and cultural purposes, $26 \%$ for green open spaces, and $11 \%$ for roads (Xavier, 2007, p. 68). These proportions refer to the general city layout, considering the main road system and the blocks' basic outlines. The internal layout of each macroblock was to additionally allocate $35 \%$ of its area for roads, institutional buildings and open spaces. A contemporary new town like the modernist Abuja presented similar land use allocation: 33.2\% for residential, $21.9 \%$ for commercial and services, $25 \%$ for open spaces, $19.9 \%$ for roads (Abubakar, 2014, p. 84).

Palmas' residential macroblocks were to house a population of between 8,000 and 12,000 inhabitants. Designed as an adaption of the neighbourhood unit, they were to contain an outer green belt and have only two entrances, which would enhance their insular environment. Irregular secondary roads would lead to the residences. Schools and other public facilities were to be settled on their central cores in free configurations, with just one set of items being predefined: density (up to 300 inhabitants/hectare), the existence of vicinal commerce along their edges and basic social and religious facilities (Teixeira et al., 1991, p. 106; Teixeira, 2009, p. 95). The internal parcelling of each macroblock, in order to create micro-blocks, was to be designed by a different architect (Figure 5) ${ }^{2}$.

\footnotetext{
${ }^{2}$ Like Palmas', Abuja's local residential neighbourhoods were planned by local planners in order to provide a range of housing alternatives within the framework allowed by the service and transportation system. In each neighbourhood, a centre provides facilities such as a kindergarten, a shopping centre and a park. Abuja is dominated by curvilinear and gridiron patterns, and its urban form is clearly based on the garden-city concepts of low density and landscaping (Abubakar, 2014, p. 84). An adaptation of the neighbourhood unit can also be seen in the layout proposed for Dodoma (see Siebolds \& Steinberg, 1980).
} 


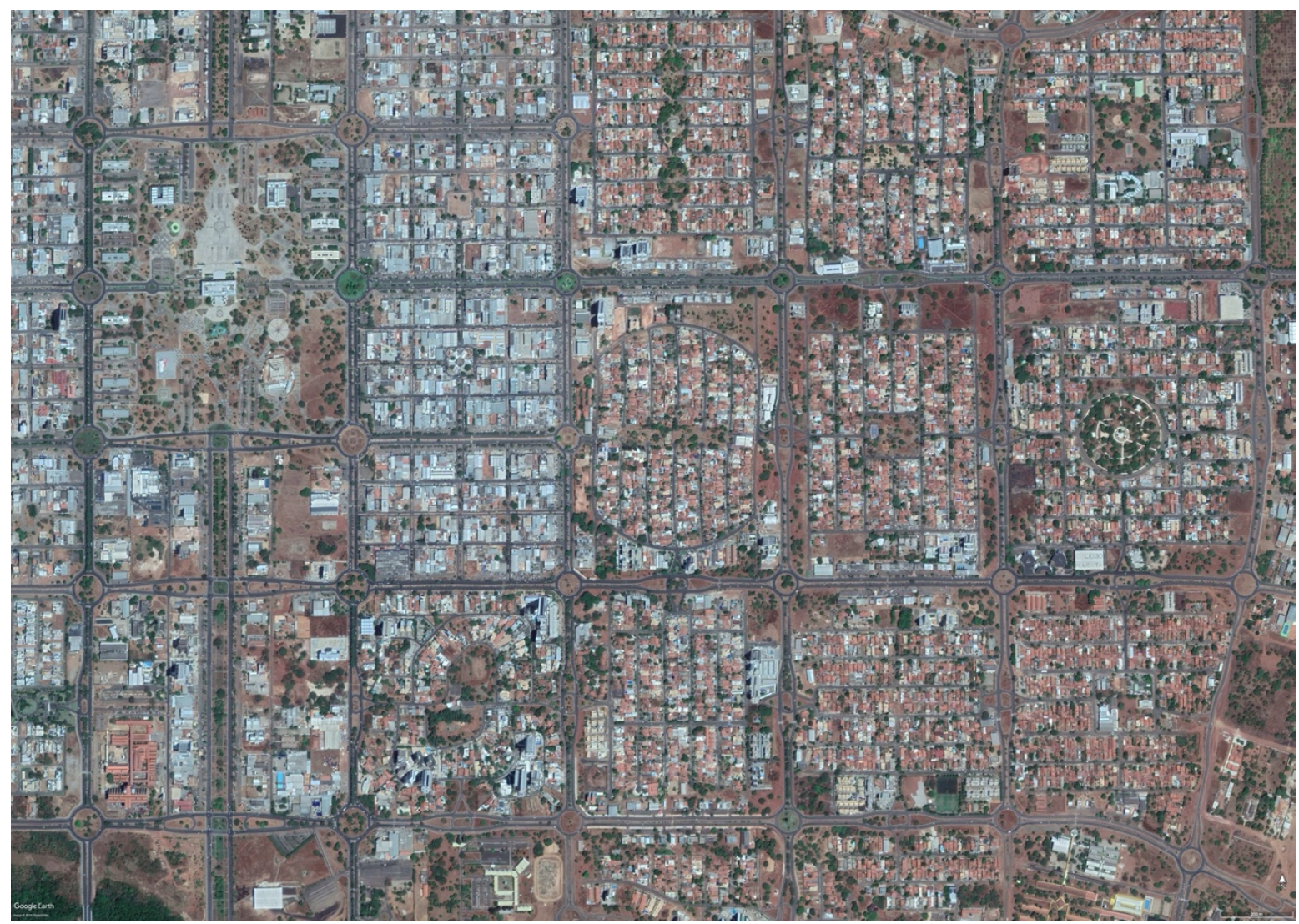

Figure 5 - Aerial view of Palmas: civic centre on the left; commercial block in the centre and residential macroblocks and their unique layout on the right. Source: Google (2018).

Palmas' planners considered the residential areas as a collection of neighbourhoods (Trindade, 2009, p. 67-68) - "[...] an urban agglomerate... constructed according to social contingencies and forces" (Segawa, 1991, p. 94) - and thus insisted on having variety within each macroblock design. Unlike Brasília's superblocks, in Palmas' macroblocks urban land property is private and plot parcelling was to offer distinct forms of spatial organization and internal townscape. Considering the potential need for single-family and multi-family dwellings, distinct residential types were foreseen: detached single houses, grouped houses and apartment buildings (GrupoQuatro, 1991, p. 98).

According to the planners' discourse, in contrast to that of Brasília, the intention of the design was to adopt an individual scale, with the single-family residence being the starting point of block organization as a response to the conventional citizen whose urban reference was the detached house, private plots and street corners - a clear reference to a more traditional urban setting (Trindade, 2009, p. 73-74). Internal roads were to promote social integration and the core of the neighbourhood was to stimulate community life by being a meeting point. Palmas' macroblocks can be understood as a gigantic, geometric adaptation of Clarence Perry's concept and, like in Radburn and Goiânia, present an inward configuration.

The identity of each macroblock would be noticed through its unique internal arrangement. In clear contrast to Brasília, Palmas' outline rejected the modernist standardized-housing and the uniformity of the superblock in favour of a more heterogeneous townscape (see Teixeira et al., 1991, p. 106). It conveys a less authoritarian structure (and more "democratic" outline) than Brasília's superblocks: its flexibility can be seen as a reaction to modernist planning. Palmas' layout did not aim to create a new social order as Brasília's did. Although Palmas' layout rejected the modernist utopia (see Velasques, 2010; Trindade, 2009, p. 69; Cocozza, 2007, p. 106), it did not completely dismiss fundamental modernist ideas and certain principles of the Charter of Athens. 


\section{The built city}

Palmas, like Brasília, demonstrates that modernism alone does not produce a better city; it simply yields a city with a distinct urban form (Siembieda, 2009, p. 294). Even though some criticism can be made about the city's outline, the original plan was neither thoroughly followed nor fully implemented, and its appropriation has also been responsible for transformations in the resulting built urban form.

Focusing back on Africa, where a new wave of constructing planned cities is emerging, Van Noorloos \& Kloosterboer (2018) understood that both new cities planned from scratch and self-contained enclaves on the outskirts of existing cities have emanated from neoliberal urban strategies. "As developers and speculators are creating new urban space and monopolising space, land is increasingly privatised and commoditised worldwide. Gentrification and land price increases can work to exclude the poor in more direct ways" (Van Noorloos \& Kloosterboer, 2018, p. 1234). Moreover, gated communities based on status and wealth, fencing themselves off with walls and private security and, thus, diminishing the possibility of meaningful social interaction and threatening the liveability of cities, were also noticed. A similar criticism can be applied to Palmas (see Albieri, 2018), as discussed further below.

According to the original plan, land development was to move from the city centre out, initially towards the south and always in east-west strips to lower the initial cost of infrastructure and to guarantee harmonious urban growth. However, the local government acted as the main land speculator, and the planned urban growth was not respected as successive municipal administrations surrendered to the capitalist production of urban space and the pressure from the real-estate market and the state government, compromising the city's plan and the final built environment. People who could not afford to comply with the zoning requirements and plot's values were thus excluded to the peri-urban area and the neighboring town beside the river.

Although some residential areas of central Palmas are barely occupied (Bazolli, 2009, p. 115; Albieri, 2018, p. 199; Trindade, 2009, p. 77; Velasques, 2010, p. 213; USP, 2008, p. 8), municipal authorities themselves, in accordance with private investors and rural land owners, have granted the expansion of the urban fabric (Albieri, 2018, p. 223). In 1991 more than three thousand new residential plots were approved outside the boundaries of the original city plan (USP, 2008, p. 14). Interestingly, these settlements present conspicuous urban vitality and typological diversity through mixed-use buildings, high densities, more traditional parcelling and a lack of functional zoning. Vila União, on the northern limit of the original layout, became a lively neighbourhood, "[...] another city within the city", due to strong cultural bonds and the rejection of the initial planned layout (Cocozza, 2007, p. 137). Gated communities have been built in the original city layout while the urban core is still empty. The social housing policy has not progressed as needed and the actual needs of the population have not been effectively addressed. According to Teixeira (2009, p. 98), one of Palmas' planners, the government policy provoked spatial segregation, anticipating a situation that would take much longer for the real estate market to establish. Although the city's economic development has profited from the exploitation of urban space, Palmas has been losing out as a social entity.

The original design concept was intended to enhance social integration, so no walls were imagined between houses within the macroblocks. However, not only were walls subsequently permitted, they were also allowed to grow higher than 1.5 metres, blocking visual contact between public and private areas, and isolating the public squares, which then became quite dangerous places (USP, 2008, p. 8. Figure 6). Consequently, many of these public, and meant-to-be cosy, squares are currently either completely abandoned or poorly maintained. The decrease in urban vitality is noticeable when the macroblocks are compared to the neighbouring settlements. Residential and public buildings in the macroblocks linked by pedestrian walkways were designed to create opportunities for social integration, which has also not occurred. Worst still, gated communities have blocked of entire macroblocks. The initial layout of the city allowed for $26 \%$ of its area to be green spaces. However, maintenance of these spaces turned out to be problematic due to their discontinued use and the irregular occupation of the urban area (USP, 2008, p. 8). Yet Palmas has a notable system of green spaces, which deserves improvement to become more attractive, particularly the public squares in the macroblocks. 


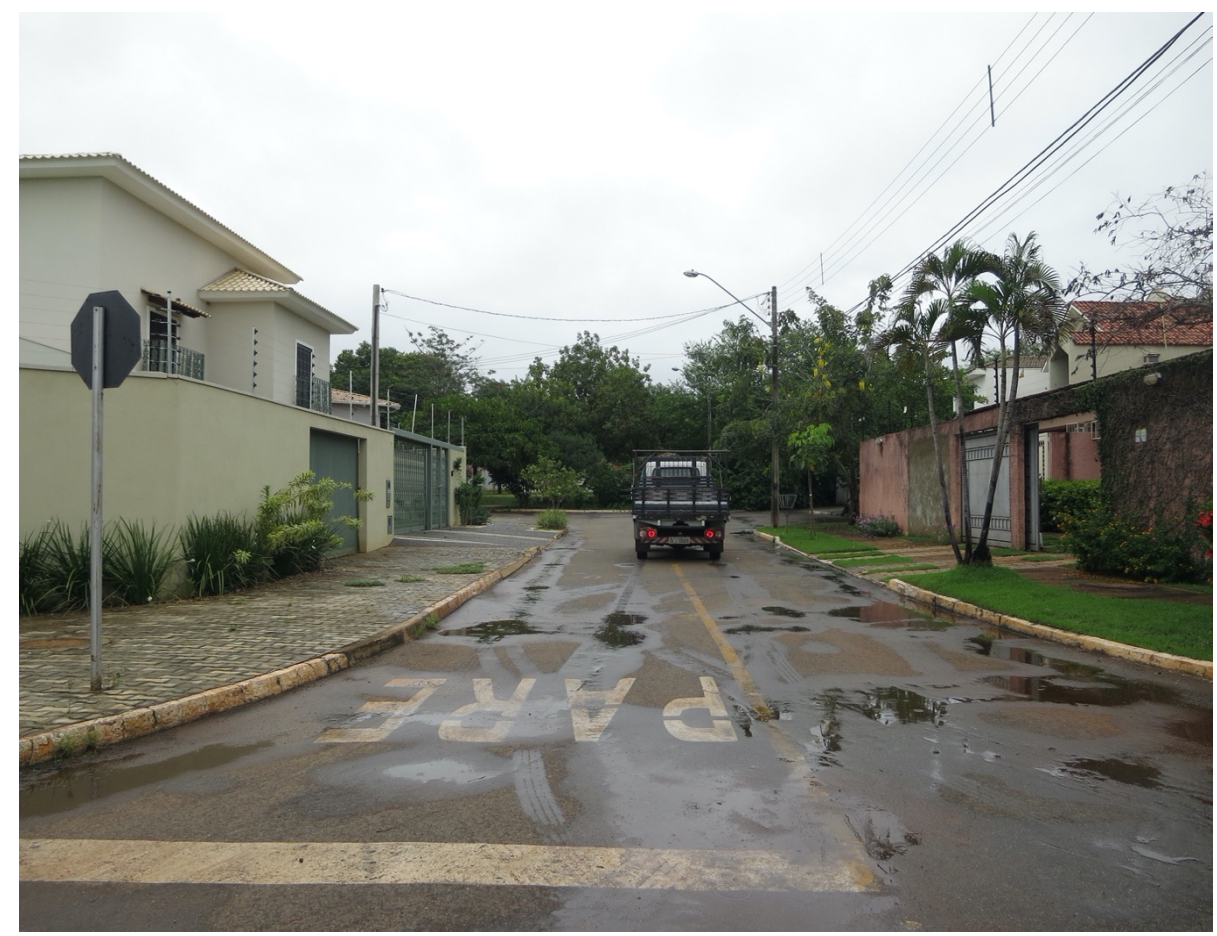

Figure 6 - Internal view of a residential macroblock, 2017. Source: The author.

The central main square, the civic centre, depicts buildings scattered amid parking areas and green pedestrian zones. It reproduces the modernist city space with its continuous void and dispersed buildings. In general, the scale of the city seems oversized (Reis, 2015b, p. 126); for example, the main urban axis - two avenues of four lanes each, plus parking areas on each side, median strip and compulsory setbacks - amounts to a width of 150 meters, while neighbouring buildings are lower than just a few storeys (Figure 7). Total population density in 2011 was roughly 9 inhabitants per hectare (Albieri, 2018, p. 205); even in consolidated blocks it did not surpass 65 inhabitants per hectare (USP, 2008, p. 14).

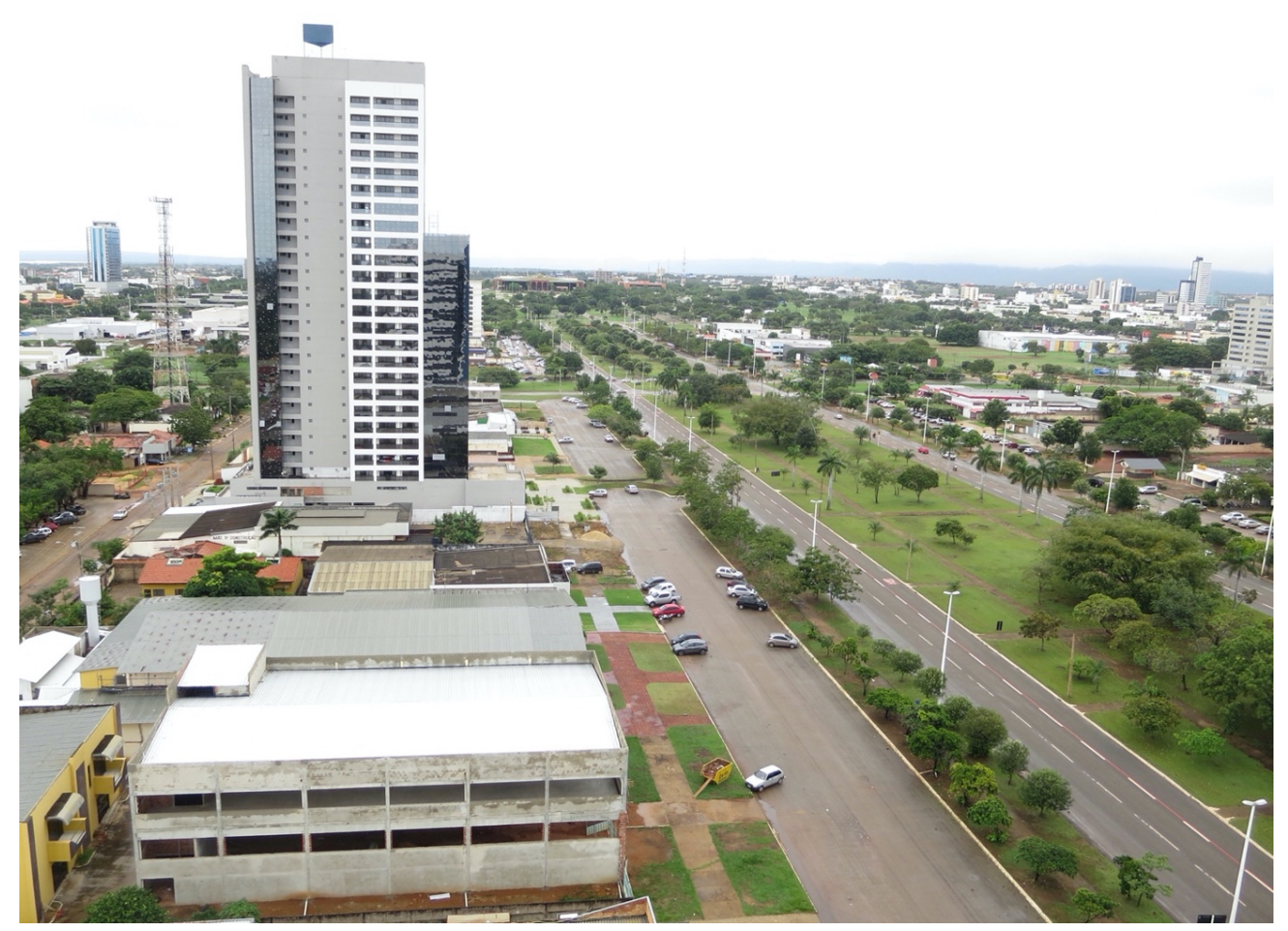

Figure 7 - Palmas main axis, 2017. Source: The author. 
The streets of Palmas have no names and addresses are based on a complex, impersonal, more complicated system than those found in modernist Brasília and Chandigarh. In Palmas, avenues and streets are named after a combination of cardinal and collateral points; blocks are specified by land use and numbered, in sequence, from the centre to the north and south edges of the city and to the east and west borders; for example, ASR-SE 115 (Regional Services Area, 115, to the South, on the East side) and AR-SO 115 (Residential Area 115 to the South, on the West (Oeste) side (Lira, 2011, p. 209). A second system is also in use in order to make it simpler: macroblocks are identified by cardinal points and numbered (even numbers to the west of the main urban axis, odd numbers to the east) in sequence from the centre to the edge of the city; for example, $204 \mathrm{SO}$, refers to a block in the south area, west side, second row, fourth column. The confusion grows stronger when it comes to the inner macroblocks, which have unique layouts. Their unfamiliar singularity, the insular situation and the puzzling arrangement of internal streets might sometimes turn them into mazes. Citizens hardly grasp the city layout and find it tedious (Reis, 2015b, p. 126 and 128).

Modernist town layouts in Brazil, particularly alien neighbourhood-unit configurations, have been transformed by citizens who have not passively complied with them and adapted the idealized urban environment to their practical needs and cultural preferences, thus revealing conflicts between the planners' visions and the appropriation and use of the urban forms: mismatches between how they were imagined and how they were lived (Rego, 2017b, 2018). Palmas' macroblocks have also endured physical transformations due to a certain rejection of the city's idealized urban life. The macroblock infrastructure does not seem to complement people's everyday-life necessities and daily routines: distances are huge, the population is dispersed and the public-transportation system is expensive and inefficient. In 2008, Palmas had 2.6 inhabitants per car, which endorses its image as a city for the automobile and repudiates the idea of it being a walkable-city. The flat terrain favours cycling, but high temperatures and scarce street arborization are considerable setbacks to this.

Real-estate companies have complained about the low value of commercial plots due to the mono-functionality of the blocks and pointed to the necessity of mix-used buildings (USP, 2008, p.10). Vicinal commerce areas, nestled on the edges of residential macroblocks, face the adjacent avenue and, thus, their rear entrances and dock areas face the house façades, in implied contempt for those plots. In fact, commerce has popped up among the residences in the macroblocks, changing the initial idea and creating a more dynamic, lively environment. Conversely, commercial blocks turn into dodgy, uninhabited places during non-working hours.

A nearby dam constructed in 2002 gave rise to a reservoir that improved the city's scenery (Trindade, 2009, p. 66; Reis, 2015a, p. 18 and 70-71). The reservoir brought the distant river water closer to the city and sandy beaches were created. A lakeshore preservation area has assured its public use and prohibited inappropriate land usage. The lakeshore park has considerably improved the city's leisure options and became a popular attraction. Nonetheless, the bridge over the reservoir fostered urbanization on Palmas' opposite shore, which offers inferior (and cheaper) urban conditions.

\section{Concluding remarks: challenges for sustainable development}

Palmas' outline rejects and, at the same time, strongly endorses Brasília's design. The last capital city planned in twentieth-century Brazil was site-purposed and designed upon ecological considerations; its gridiron fitted natural conditions and the resulting urban form is strongly related to the landscape. Yet, Palmas is a city for the automobile. Modernist in its super-wide avenues and great distances between civic buildings, the large-scale street network with its dependence on the motorcar is a negative aspect of its layout (Figure 8). 


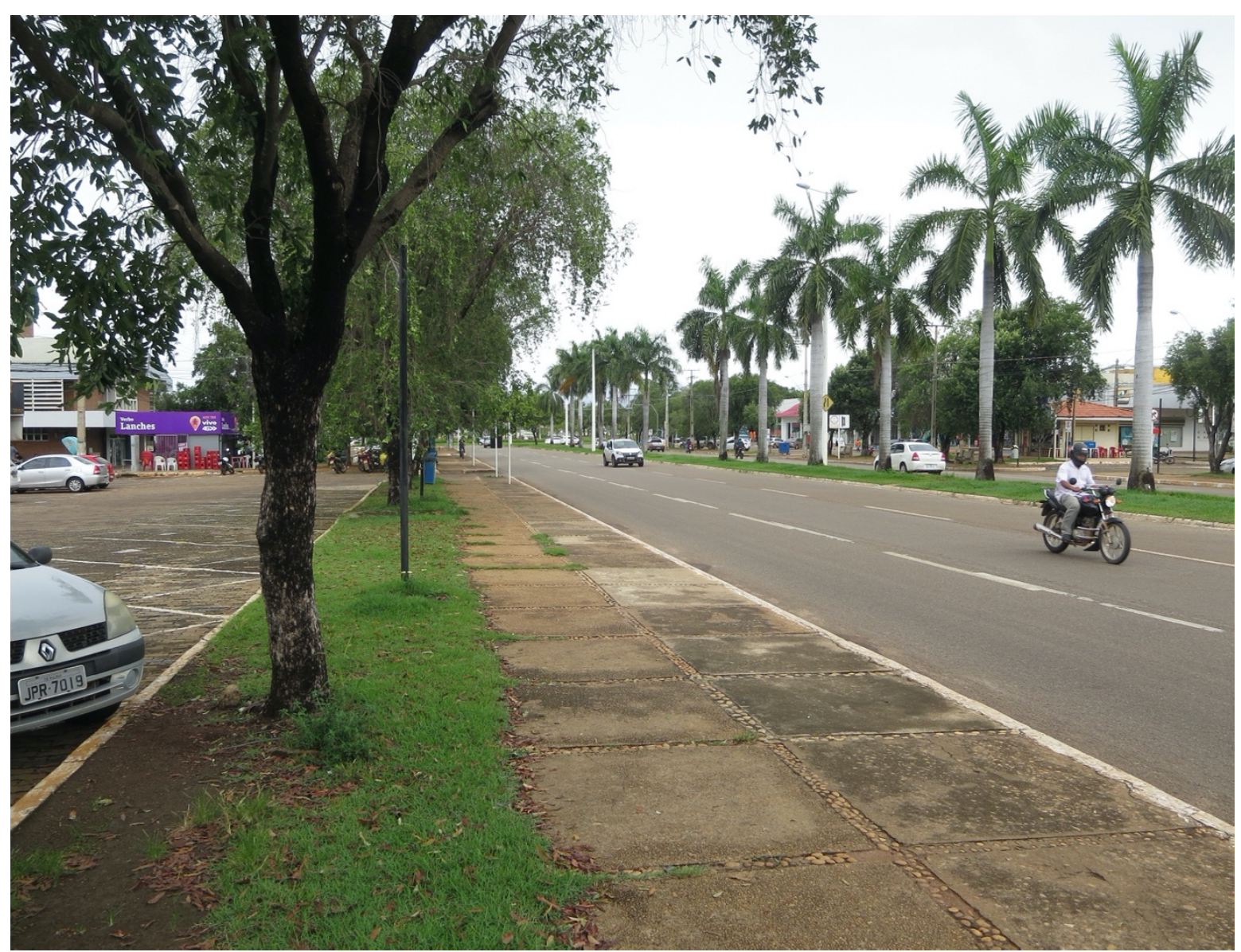

Figure 8 - View of Avenue Juscelino Kubitschek (an East-West commercial road), 2017. Source: The author.

Palmas' neighbourhood units are another legacy of modernist urbanism. Its plan insisted on single-use neighbourhoods when this had long been contested in favour of more urban diversity (Jacobs, 1961). The town layout has allowed diversity in the inner form of its macroblocks - to the extreme of the uniqueness of each macroblock - but not in their uses, which results in reduced vitality. Though avoiding the modernist standardization, the varied outline of the macroblocks lacks legibility.

The city layout has fulfilled its symbolic role. The civic centre has eluded Brasília's monumentality, although the arrangement of its public buildings and governmental palace upon a vast green square recalls the modernist city's organization. The Tocantins state's new capital city, as well as the new capital cities in developing countries, has been responsible for creating economic growth and spreading regional development: urbanization and prosperity correlate. However, social inequalities have also been produced, for modernist forms tend to reinforce spatial and social exclusion, and produce cities which are not environmentally sustainable (UN-Habitat, 2009, p. 58). Despite having been planned from scratch, Palmas also presents the socio-spatial segregation seen in other planned new cities. The process of socio-spatial segregation in Palmas was initiated by the public administration itself.

Some of its major urban problems date back to the implementation of the original plan and some to the city's administration: large tracts of land left empty within fully serviced areas, violations of land-use regulations, squatter settlements in surrounding areas, low population density and an inefficient public-transportation system among them. More efficient management is needed in order to reverse the exclusionary nature of its urbanization.

From the start, the city's design disregarded the modernist utopia of shaping a new social order through urbanism and architecture, but Palmas' urban life was still, to a great extent, an idealized one, as depicted by its functional sectors, land-use segregation and the insular structure of the neighbourhood units. The macroblocks have lacked a sense of community and, with regard to these aspects, the 
surrounding settlements might be able to teach a valuable lesson. The urban area should be reduced in order to promote density and mitigate its sense of emptiness. Such shrinking would enhance urban greatness. The cost of urban infrastructure per inhabitant in Palmas was the highest in Brazil in 2005 (Bazolli, 2009, p. 116 and 118) and, unarguably, the denser the city the cheaper its infrastructure (UN-Habitat, 2009, p. 29). The increase in block density through infill, to create a more efficient relationship between the cost of urbanization and urban density, should be seriously addressed by the public administration. Fostering mixed land use in the residential zones - like in the surrounding settlements - by reconsidering the current building regulations, would certainly increase urban vitality. New building regulations should also encourage social mixing along with mixed land use, with a view to offering an attractive spectrum of services, housing and working opportunities for a wide range of the population.

Moreover, it is of great urgency to ensure that planning rules and regulations are really implemented and functionally effective. Likewise, it is necessary to manage the land market in order to recover part of the public investment made in urban infrastructure and services. It is also necessary to ensure that low-income areas are upgraded and integrated into the urban fabric. Furthermore, it would be desirable to improve and revitalize existing public spaces and make them safer, as Palmas' system of green open spaces can be regarded as a great opportunity to enhance its ecological structure.

Planning, layout and structures are easier to conceive and regulate; people, social behavior and the effects of policies are much less predictable. Thus, the challenges of Palmas' urban management are not so different to those of similar modernist new towns in developing countries. The main tasks in order to cope with the challenges to the urban development of Palmas include the development of a comprehensive strategy for sustainable urban development; creation of higher densities by intensification of land use through the rezoning and occupation of empty urban lands; re-development of mono-structured areas with a variety of functions; application of the principle of social mix for better integration between different groups; re-development of open spaces and implementation of greening, cleaning and maintenance; and the implementation of an efficient public-transport system. This may bring Palmas closer to its initial image of an ideal new capital city.

\section{Acknowledgements}

This research was funded by Conselho Nacional de Desenvolvimento Tecnológico e Científico - CNPq.

\section{References}

Abubakar, I. R. (2014). Abuja city profile. Cities, 41, 81-91. http://dx.doi.org/10.1016/j.cities.2014.05.008.

Abubakar, I. R., \& Doan, P. L. (2010). New towns in Africa: modernity and/or decentralization. In Proceedings of the 53rd African Studies Association Annual Meetings. San Francisco, CA: ASA.

Alayande, J. F. (2006). Abuja: readings in city planning. Lexington: Booksurge Com.

Albieri, L. (2018). Sistema de espaços livres e a constituição da forma urbana contemporânea.Produção e apropriação em Palmas - TO. In S. S. Macedo, E. F. Queiroga, A. C. A. Campos, \& V. Custodio (Eds.), Quadro geral da forma e do sistema de espaços livres das cidades brasileiras (pp. 199-236). São Paulo: FAUUSP.

Almandoz, A. (2008). Despegues sin madurez: urbanización, industrialización y desarrollo en la Latinoamérica del siglo XX. EURE: Revista Latinoamericana de Estudios Urbano Regionales, 34(102), 61-76. http://dx.doi.org/10.4067/S0250-71612008000200004.

Almandoz, A. (2015). Modernization, urbanization and development in Latin America (pp. 1900s-2000s). London: Routledge. 
Bazolli, J. A. (2009). Os efeitos dos vazios urbanos no custo de urbanização da cidade de Palmas - TO. Estudos Geográficos, 7(1), 103-123. Retrieved in 2019, March 16, from

http://www.periodicos.rc.biblioteca.unesp.br/index.php/estgeo/article/view/541/3308

Bittar, R. (1988, 1 de novembro). Tocantins nasce em clima de discórdia (pp. 40). São Paulo: O Estado de São Paulo.

Cain, A. (2014). African urban fantasies: past lessons and emerging realities. Environment and Urbanization, 26(2), 561-567. http://dx.doi.org/10.1177/0956247814526544.

Camargo, J. G. C. (1973). Urbanismo rural. Brasília: Ministério da Agricultura/INCRA.

Cocozza, G. P. (2007). Paisagem e urbanidade: os limites do projeto urbano na conformação de lugares em Palmas (Doctorate thesis). Universidade de São Paulo, São Paulo. http://dx.doi.org/10.11606/T.16.2007.tde-29042010114302.

Del Priore, M., \& Venancio, R. (2010). Uma breve história do Brasil. São Paulo: Planeta.

Del Rio, V. (2009). Historical background. In V. Del Rio, \& W. Siembieda (Eds.), Contemporary urbanism in Brazil: beyond Brasília (pp. 1-36). Gainesville: University Press of Florida.

Gomes, A. C. (Ed.). (2013). Olhando para dentro: 1930-1964. Rio de Janeiro: Objetiva.

Google. (2018). Google Earth website. https://www.google.com/earth/.

Gorelik, A. (2005). Das vanguardas a Brasília: cultura urbana e arquitetura na América Latina. Belo Horizonte: Universidade Federal de Minas Gerais.

GrupoQuatro. (1991). A concepção da nova capital. Revista Projeto, 146, 95-102.

Hayuma, A. M. (1980). Dodoma: the planning and building of the new capital city of Tanzania. Habitat International, 5(5-6), 653-680. http://dx.doi.org/10.1016/0197-3975(80)90007-7.

Holston, J. (1989). The modernist city: an anthropological critique of Brasilia. Chicago: The University of Chicago Press. Instituto Brasileiro de Geografia e Estatística - IBGE. (2017a). Palmas: panorama. Rio de Janeiro: IBGE. Retrieved in 2019, March 15, from https://cidades.ibge.gov.br/brasil/to/palmas/panorama

Instituto Brasileiro de Geografia e Estatística - IBGE. (2017b). Palmas: monografias municipais. Rio de Janeiro: IBGE. Retrieved in 2019, March 15, from https://biblioteca.ibge.gov.br/visualizacao/periodicos/2974/momun_no_to_palmas.pdf

Jacobs, J. (1961). The death and life of great American cities. New York: Random House.

Kran, F., \& Ferreira, F. P. M. (2006). Qualidade de vida na cidade de Palmas - TO: uma análise através de indicadores habitacionais e ambientais urbanos. Ambiente \& Sociedade, 9(2), 123-141. http://dx.doi.org/10.1590/S1414$753 X 2006000200007$.

Lara, F. L. (2018). Arquitetura moderna brasileira e o automóvel. In F. L. Lara (Ed.), Excepcionalidade do modernismo brasileiro (pp. 200-225). São Paulo: Romano Guerra.

Lima, A. C. (1937). Goiânia, a nova capital de Goiás. Arquitetura e Urbanismo, 2, 140-146.

Lira, E. R. (2011). A gênese de Palmas - Tocantins: a geopolítica de (re)ocupação territorial na Amazônia legal. Goiânia: Kelps.

Moraes, A. C. R. (2008). Território e história no Brasil. São Paulo: Annablume.

Mumford, E. (2000). The CIAM discourse on urbanism: 1928-1960. Cambridge: The MIT Press.

Mumford, E. (2009). Defining urban design. CIAM architects and the formation of a discipline, 1937-69. New Haven: Yale University Press.

Osborn, F. J., \& Whittick, A. (1977). New towns: their origins, achievements and progress. London: Leonard Hill.

Rego, R. L. (2014). Brazilian garden cities and suburbs: accommodating urban modernity and foreign ideals. Journal of Planning History, 13(4), 276-295. http://dx.doi.org/10.1177/1538513214521582. 
Rego, R. L. (2017a). Shaping an urban Amazonia: 'a planner's nightmare'. Planning Perspectives, 32(2), 249-270. http://dx.doi.org/10.1080/02665433.2016.1277952.

Rego, R. L. (2017b). Unidade de vizinhança: um estudo de caso das transformações de uma ideia urbanística. URBE, 9(3), 401-413. http://dx.doi.org/10.1590/2175-3369.009.003.ao01.

Rego, R. L. (2018). Neighbourhood units in Brazilian new towns: foreign idea and local urban life. In Proceedings of the 18th International Planning History Society Conference. Yokohama: IPHS. https://doi.org/10.7480/iphs.2018.1.2725.

Reis, P. O. B. (2015a). Palmas: um projeto e múltiplos olhares. Palmas: EDUFT.

Reis, P. O. B. (2015b). Palmas: uma cidade em busca de significados. In P. O. B. Reis (Ed.), Palmas: um projeto e múltiplos olhares (pp. 123-143). Palmas: EDUFT.

Rezende, V. (Ed.). (2012). Urbanismo na era Vargas: a transformação das cidades brasileiras. Niterói: UFF.

Segawa, H. (1991). Palmas, cidade nova ou apenas uma nova cidade? Revista Projeto, 146, 94-94.

Segawa, H. (1997). Arquiteturas no Brasil. São Paulo: Editora da Universidade de São Paulo.

Siebolds, P., \& Steinberg, F. (1980). Dodoma: a future African Brasília? Habitat International, 5(5-6), 681-690. http://dx.doi.org/10.1016/0197-3975(80)90008-9.

Siembieda, W. (2009). Conclusion: lessons from contemporary Brazilian urbanism. In V. Del Rio, \& W. Siembieda (Eds.), Contemporary urbanism in Brazil: beyond Brasília (pp. 291-301). Gainesville: University Press of Florida.

Teixeira, L. F. C. (2009). A formação de Palmas. Revista UFG, 11(6), 91-99. Retrieved in 2018, November 18, from https://www.proec.ufg.br/up/694/o/06_Palmas.pdf

Teixeira, L. F. C., Oliveria, W. A., Fo., \& Segawa, H. (1991). 0 ideal e o real. Revista Projeto, 146, 103-109.

Trindade, D. (2009). Challenges for new town design in a frontier region: palmas. In V. Del Rio, \& W. Siembieda (Eds.), Contemporary urbanism in Brazil: beyond Brasília (pp. 65-81). Gainesville: University Press of Florida.

UN-Habitat (2009). Planning sustainable cities: global report on human settlements. London: Earthscan.

Universidade de São Paulo - USP. Faculdade de Arquitetura e Urbanismo. (2008). Relatório Oficina-SEL Palmas - TO. São Paulo: Laboratório da Paisagem FAU-USP. Retrieved in 2018, October 24, from https://quapasel.files.wordpress.com/2011/04/9-relatc3b3rio_palmas.pdf

Vale, L. J. (2008). Architecture, power, and national identity (2nd ed.). London: Routledge.

Van Noorloos, F., \& Kloosterboer, M. (2018). Africa's new cities: the contested future of urbanisation. Urban Studies, 55(6), 1223-1241. http://dx.doi.org/10.1177/0042098017700574. PMid:30443088.

Velasques, A. B. A. (2010). A concepção de Palmas (1989) e sua condição moderna (Doctorate thesis). Universidade Federal do Rio de Janeiro, Rio de Janeiro. Retrieved in 2018, October 18, from https://minerva.ufrj.br/F/6EHAVBXD8PF9L11NX4QN9CF4KDM4KQHK3VSHA1PK8263KATFAI-55667?func=shortrank\&action=RANK\&W01=A\&W02=concepção\&W03=de\&W04=Palmas\&W05=1989

Wakeman, R. (2016). Practicing utopia: an intellectual history of the new town movement. Chicago: Chicago University Press. http://dx.doi.org/10.7208/chicago/9780226346175.001.0001.

Xavier, F. O. R. (2007). Palmas: uma cidade para todos? (Master dissertation). Universidade Federal do Paraná, Curitiba.

Editor: Rodrigo Firmino

Received: July 08, 2019

Approved: Dec. 16, 2019 